\title{
Characterization of Microorganisms Using Raman Microscopy
}

\author{
Danka Radić
}

\begin{abstract}
Raman spectroscopy has recently gained popularity as an attractive approach for the biochemical characterization, rapid identification, and an accurate classification of a wide range of prokaryotes and eukaryotes organisms. In the case of eucariotes it is necessary to obtain higher number of Raman spectra in order to perform statistical analysis and to draw conclusions.
\end{abstract}

"Raman spectroscopy (RS) is a powerful molecular fingerprinting technique which analyzes materials through the interaction of the material's molecules with an incident laser beam" (Hanlon et al., 2000).

Vibrational spectroscopic technique, Raman spectroscopy (RS), has been used extensively to identify samples of different microorganisms by a careful investigation of the vibrating modes of the molecules in the microorganisms (Rösch et al. 2005). Raman spectroscopy has recently gained popularity as an attractive approach for the biochemical characterization, rapid identification, and an accurate classification of a wide range of prokaryotes and eukaryotes organisms (Hamasha 2011).

How to cite this book chapter:

Radić, D. 2019. Characterization of Microorganisms Using Raman Microscopy. In:

Vucelić Radović, B., Lazić, D. and Nikšić, M. (eds.) Application of Molecular

Methods and Raman Microscopy/Spectroscopy in Agricultural Sciences and Food

Technology, Pp. 161-165. London: Ubiquity Press. DOI: https://doi.org/10.5334/

bbj.k. License: CC-BY 4.0 
The Raman spectra of the microorganisms are superposition of spectra of the biochemical components inside the cells like e.g. protein, DNA, RNA, lipids, carbohydrates, water, as well as a few components with minor concentrations (Rösch et al. 2011).

Accordingly, the Raman spectra of two different species or strains show minor variations which originate from different chemical compositions due to variations in e.g. the cell wall (Rösch et al. 2011).

For the Raman spectroscopic characterization of eukaryotes like yeasts or fungi, different approaches are mandatory. It is not recommendable to use only one Raman spectra, in case of eukaryotes, because of the variations due to various organelles. An average of fifty spectra is necessary in order to perform statistical analysis and to draw conclusions. On this basis, it can be concluded, that the Raman spectroscopy can be used to identify yeasts or fungi (Stöckel et al. 2015).

For example, distribution of the width of the bands mirrors the different compounds and parts of the yeast cell (Figure 1a). Characteristic $\mathrm{C}=\mathrm{O}$ stretch vibrations (1731-1765 $\mathrm{cm}^{-1}$ ) represent the lipid fraction; mapping over the amide I region $\left(1624-1687 \mathrm{~cm}^{-1}\right.$ ) produces bands arousing from the $\mathrm{C}=\mathrm{C}$ lipid bonds. The phenylenic $\mathrm{C}=\mathrm{C}$ Raman band $\left(1567-1607 \mathrm{~cm}^{-1}\right)$ can be only seen in the periphery of the cells (Rösch et al., 2005).

During recording of a spectrum problems can occur. Fluorescence often appears when the examined material is complex and in color (Figure 1b), (Jang and Akkus, 2013). Another problem that might appear is burning of a sample (Figure 1c).

\section{Preparation of the sample}

\subsection{Yeasts}

The yeast cells were incubated at $28^{\circ} \mathrm{C}$ in a nutrient-rich YPD medium. Aliquots of the cell suspension were centrifuged (3000 rpm, 2min), washed three times with sterile water, and final suspended in the new aliquot of water (original suspension: water $=1: 9)$. Spectra of the yeast (Fig. 1a).

\section{Acquisition parameters}

Recommendations for the spectra recording:

Laser wavelength: $532 \mathrm{~nm}$, Greeting: $1200 \mathrm{gr} / \mathrm{mm}$, Slit: $50 \mu \mathrm{m}$, Hole: $500 \mu \mathrm{m}$, Acquisition time: 20s, Range: $400-3200 \mathrm{~cm}^{-1}$. Use a quartz plate!

\subsection{Bacteria}

The bacteria cells were incubated at $30^{\circ} \mathrm{C}-37^{\circ} \mathrm{C}$ in an appropriate nutrient-rich medium.

Sample preparationis the same as for the yeasts! 


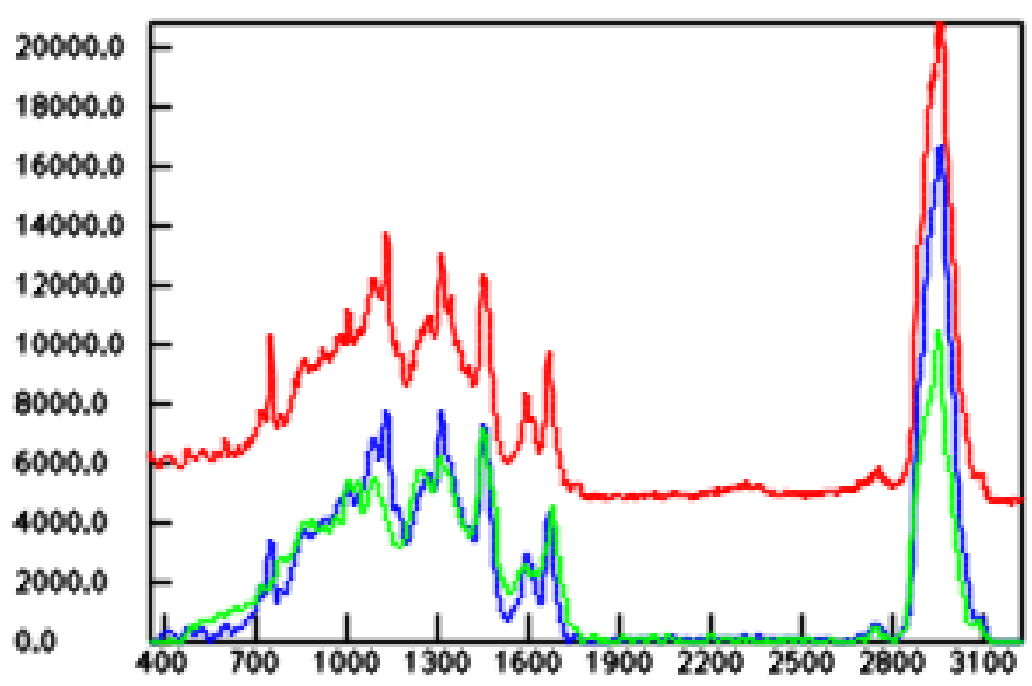

Figure 1a: Spectrum of the yeast. Different pronounced bands originated from lipids and proteins can be observed.

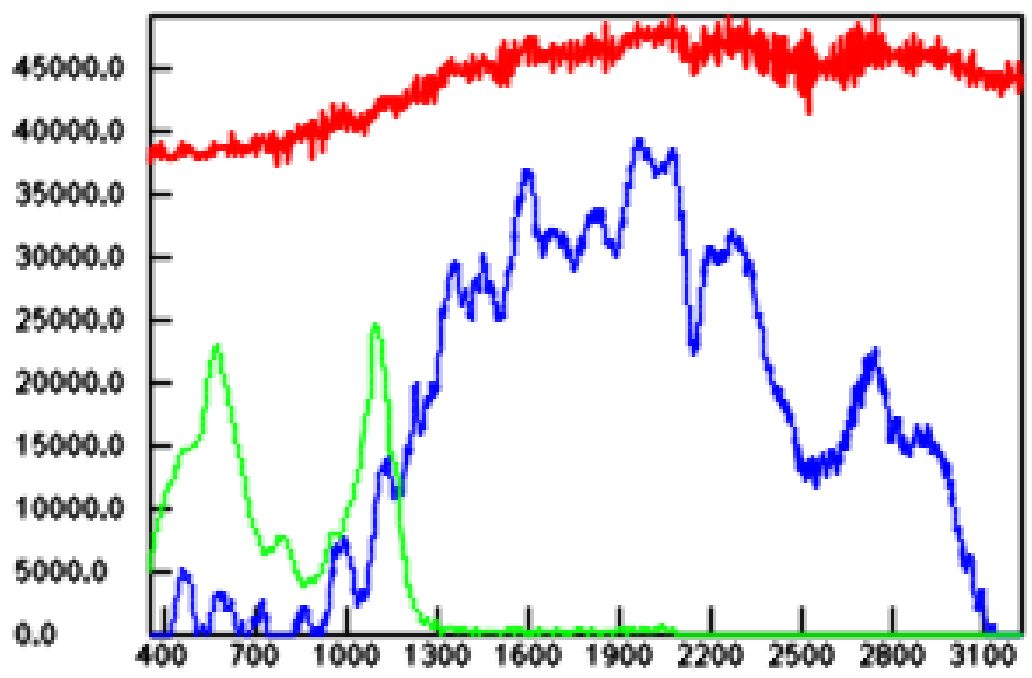

Figure 1b: Spectrum of fluorescence is marked by red label. 


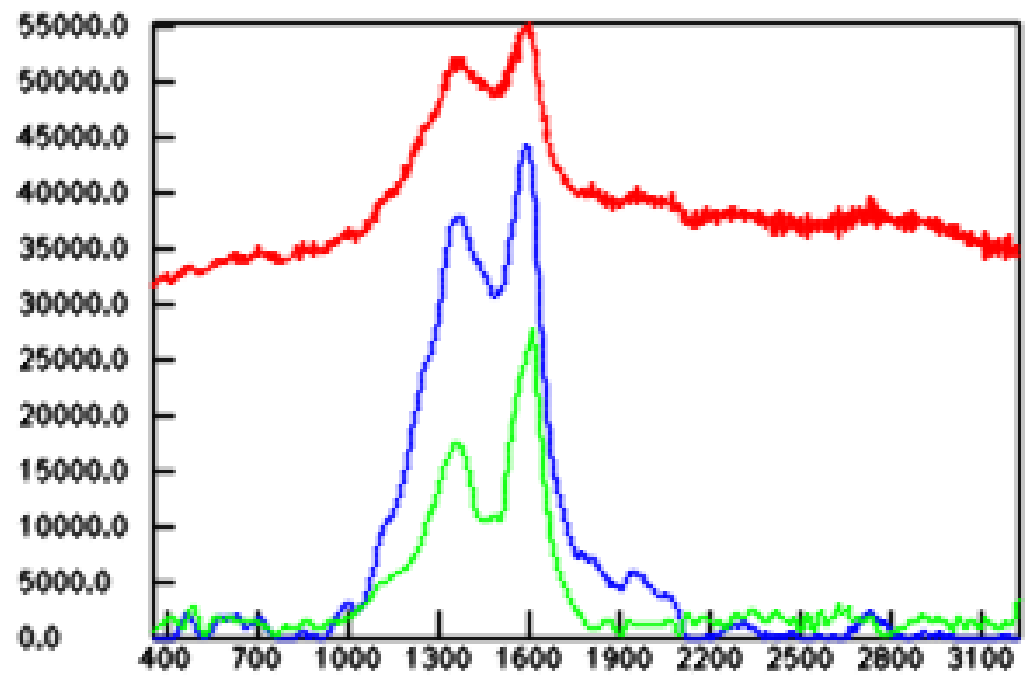

Figure 1c: Spectrum of burned cells is presented by red label.

\section{Acquisition parameters}

Recommendations for shooting:

Laser wavelength: $532 \mathrm{~nm}$, Greeting: $600 \mathrm{gr} / \mathrm{mm}$, Slit: $50 \mu \mathrm{m}$, Hole: $500 \mu \mathrm{m}$, Acquisition time: 30 s, Range: $400-3200 \mathrm{~cm}^{-1}$. Use a quartz plate!

In addition: All obtained spectra have to be processed using $\mathrm{R}$ program, which includes: spike removal, calibration, background removal, cutting, vector normalization, removing of the silent region.

\section{References}

Hamasha, K. M. (2011). Raman spectroscopy for the microbiological characterization and identification of medically relevantbacteria (Doctoral dissertation, Wayne State University)

Hanlon, E. B., Manohran, R., Koo, T. W., Shafer, T. W., Motz, J. T., Fitzmaurice, M., Kramer, J. R., Itkazan, I., Dasari, R. R., \& Feld, M. S. (2000). Prospects for in vivo Raman spectroscopy. Physics in Medicine \& Biology, 45(2), R1 59.

Rösch P., Harz, M., Peschke, K.D., Ronneberger, O., Burkhardt, H., \& Popp, J. (2006). Identification of Single Eukaryotic Cells with Micro-Raman Spectroscopy. Biopolymers, 82, 312-316. DOI: https://doi.org/10.1002/bip.20449 
Rösch, P., Harz, M., Schmitt, M., \& Popp. J. (2005). Raman spectroscopic identification of single yeast cells. Journal of Raman Spectroscopy, 36, 377-379. DOI: https://doi.org/10.1002/jrs.1312

Rösch, P., Stöckel, S., Meisel, S., Münchberg, U., Kloß, S., Kusic, D., Schumacher, W., \& Popp, J. (2011, November). A Raman spectroscopic approach for the cultivation-free identification of microbes. Paper presented at the SPIE 8311, Optical Sensors and Biophotonics III, Shanghai, China. DOI: https:// doi.org/10.1117/12.901241

Stöckel, S., Kirchhoff, J., Neugebauer, U., Röscha, P., \& Popp, J. (2015). The application of Raman spectroscopy for the detection and identification of microorganisms. Journal of Raman Spectroscopy, Special Issue: International Year of Light, 47(1) 89-109. DOI: https://doi.org/10.1002/jrs.4844

Yang, S. Akkus, O. (2013). Fluorescence Background Problem in Raman Spectroscopy: Is $1064 \mathrm{~nm}$ Excitation an Improvement of 785nm, Wasatch Photonics: Report 2013. 
